\title{
An Application of Conventional Sovereign Debt Sustainability Analysis to the Current Debt Crises
}

\author{
$\underline{\text { Silvio Contessi }}$
}

\begin{abstract}
The developing international debt crisis has unleashed unanticipated fears that more governments in some advanced economies may default on their sovereign debt and trigger a global financial tsunami. This article provides a primer on sovereign debt sustainability and interprets the recent experience of advanced economies in the light of a uniform approach that allows an answer to this question: What are the main factors that contribute to making a country's debt sustainable or unsustainable?
\end{abstract}

(JEL E6, H12, H6)

Federal Reserve Bank of St. Louis Review, May/June 2012, 94(3), pp. 197-220.

ince the global financial crisis began in 2007, focus has intensified on the national debts of several European Union (EU) countries; the perceived risk of default on this debt has spiked to levels not seen since the introduction of the euro in 1999 and, for many countries, not since the years after World War II. The initial worries lay with four peripheral countries-Ireland, Portugal, Spain, and Greece-but extended to Italy in the summer of 2011 and started to spread to countries whose debt was considered sustainable until a few months earlier; by the beginning of 2012, France, for example, was included in this last category. As a consequence, financial markets and investors demanded higher yields to keep buying the debt issued by this group of seemingly disparate countries. Thanks to policy intervention by the European Central Bank (ECB), fiscal packages in various countries, and the restructuring of the Greek debt, yields of the government debt of euro zone countries were reduced in the first three months of 2012, suggesting a softening of the debt crisis. $\underline{1}$ This article provides a primer on sovereign debt sustainability and interprets the recent experience of advanced economies using a simple standard analysis of the elements that contribute to debt sustainability in the medium term.

Government debt $\left(D_{t}\right)$ at the end of a certain period, $t$, is typically described as a percentage of gross domestic product (GDP) or output, $\left(Y_{t}\right)$ - that is, as a debt-to-GDP ratio: $\left(d_{t}=D_{t} / Y_{t}\right) . \underline{2}$

Silvio Contessi is an economist at the Federal Reserve Bank of St. Louis. The author thanks Riccardo Di Cecio, Luciana Juvenal, Li Li, and Subhayu Bandyopadhyay for comments and Mingyu Chen, Li Li, and Lowell Ricketts for research assistance and data collection.

( ) 2012, The Federal Reserve Bank of St. Louis. The views expressed in this article are those of the author(s) and do not necessarily reflect the views of the Federal Reserve System, the Board of Governors, or the regional Federal Reserve Banks. Articles may be reprinted, reproduced, published, distributed, displayed, and transmitted in their entirety if copyright notice, author name(s), and full citation are included. Abstracts, synopses, and other derivative works may be made only with prior written permission of the Federal Reserve Bank of St. Louis. 


\section{Contessi}

This convention allows meaningful comparisons over time or across countries with respect to the ability of a government to service its debt and handle its fiscal situations in general.

The recent financial and banking crises and global recession increased annual deficits and debt-to-GDP ratios in many countries, as often occurs after such crises. In particular, Reinhart and Rogoff (2009) show in their large sample of crises that real public debt increased by 86.3 percent on average within 3 years in the aftermath of pre-2007 crises. For example, since 2007 U.S. debt has increased by 65.15 percent and for 17 euro area countries as a whole by 38.46 percent. The current monetary stance in many countries has kept interest rates at favorably low levels for the past three years and will perhaps do so for the near future. However, the global economy is likely to strengthen in the medium term and rates are likely to rise, further increasing total deficits and making government debt more difficult to sustain.

What happened in the EU countries perceived as the riskiest, at least in terms of government debt sustainability? Why did their fiscal situations deteriorate so rapidly? Although the causes for uncertainty in each country differ, all five peripheral EU countries (Italy, Ireland, Spain, Portugal, and Greece) face burdensome public debt and large, although shrinking, budget deficits. Italy had a large stock of debt for many years and experienced poor recent and expected growth. Ireland and Spain had lower pre-crisis debt but experienced huge deficit increases, and their economies are expected to perform poorly in the near future. Portugal had moderate debt but sizable deficit increases coupled with slow projected growth. Greece had both a large pre-crisis debt and a ballooning deficit.

In all countries but Ireland, common elements contribute to fiscal concerns, including a high share of government expenditure as a percentage of GDP, low fertility rates (with fewer future workers to reduce the debt), and a relatively large informal economy that makes tax collection inefficient and difficult. In addition, four of the countries (Ireland is again an exception) currently spend or are projected to spend a larger share of their GDP to pay for future public pensions relative to other advanced economies. A final common element among these countries is membership in the euro area, which presumably prevents members from inflating away their debt because the euro zone monetary policy is conducted by the ECB, an independent institution as established in the ECB statute as well as in the Treaty on European Union and Treaty on the Functioning of the European Union (the Maastricht treaty and the Rome treaty). $\underline{3}$ Two questions arise from apparently similar treatment triggered by what appear to be different causes: First, what determines the growth of national debts? And second, what common features explain why investors have been so worried about these countries as a group?

Although there are features specific to countries belonging to the euro zone, the answers to these questions more generally relate to a country's overall fiscal soundness and the notion of debt sustainability. In a nutshell, faster GDP growth relative to debt facilitates a government's efforts to keep its debt-to-GDP ratio under control. In contrast, meager economic growth and/or little fiscal discipline can balloon the debt-to-GDP ratio until the government develops fiscal discipline, defaults on its debt, or monetizes it. For countries in the euro zone, further complications stem from the fact that actions affecting money supply, inflation, and ultimately monetization of government debt are not a prerogative of national central banks but are the purview of the ECB, to which these individual countries relinquished monetary policy when they adopted the euro as their common currency and entered the euro zone. 
This article discusses the simple algebra of debt sustainability in a general case and how the recent experience of five peripheral European countries can be interpreted in the context of this analysis. Greece, Ireland, Italy, Portugal, and Spain are compared with five other countries in the G-7: France, Germany, Japan, the United Kingdom, and the United States.

The analysis is carried out as of the end of January 2012. In the first few months of 2012, the combination of policy interventions by the ECB through the two rounds of the long-term financing program, various fiscal packages in individual countries, and the restructuring of the Greek debt contributed to lower the yields of euro zone countries' government debt, suggesting that the debt crisis may be losing steam. This study does not analyze recent events or discuss the additional complications attached to euro zone membership, but it does focus directly on the determinants of debt sustainability in both a general sense and through the comparison of an array of euro zone countries. (For excellent and detailed analyses of the problems specific to the 17 members of the euro zone, see Boone and Johnson, 2011; Boone and Johnson, 2012; Holinski, Kool, and Muysken, 2012; and Martin and Waller, 2012.)

The second section discusses a simple formalization of debt sustainability. The next section interprets the recent experience of the five peripheral EU countries within the framework developed in the previous section.

\section{WHEN IS GOVERNMENT DEBT SUSTAINABLE?}

This section presents a simple textbook analysis of debt-to-GDP sustainability in a closed economy in which government debt is issued entirely in domestic currency and no external variable is factored in. $\underline{4}$ Explaining the determinants of government debt sustainability requires the definition of certain variables (see the Notation Glossary).

The annual budget constraints of the government require that expenditures (i.e., government purchases, $\left.G_{t}\right)$ plus interest on privately held outstanding debt $\left(i_{t} D_{t-1}\right)$ must be funded by three sources of revenue: taxes $\left(T_{t}\right)$, new borrowing from the private sector $\left(D_{t}-D_{t-1}\right)$, and changes in the stock of money $\left(M_{t}-M_{t-1}\right)$, denoted as follows:

$$
\underbrace{G_{t}+i_{t} D_{t-1}}_{\text {Expenditures }}=\underbrace{T_{t}+\left(D_{t}-D_{t-1}\right)+\left(M_{t}-M_{t-1}\right)}_{\text {Revenues }} \text {. }
$$

In the simplest terms, if tax receipts $\left(T_{t}\right)$ exceed government outlays on current expenditures $\left(G_{t}\right)$, the government enjoys a primary surplus; conversely, if current expenditures exceed tax receipts, then the government runs a primary deficit. (Another way of naming a deficit is to call it a negative surplus.) The term "primary" refers to the current flow of taxes and government spending, which includes both long-term structural spending (such as military expenditures or infrastructure) and cyclical components (such as unemployment benefits).

The primary surplus (or deficit) less interest payments on outstanding debt is defined as an overall (including interest) fiscal surplus if positive and overall fiscal deficit if negative. More generally, the primary balance can be defined as $B_{t}=G_{t}-T_{t}$; therefore, $B_{t}>0$ identifies a primary deficit. The government budget constraint can be reorganized to show that the year-to-year change in nominal government debt is the sum of three factors: the interest paid on outstanding debt, the primary deficit, and changes in the money supply. -5 Higher interest rates (which affect 


\section{Contessi}

\section{Notation Glossary}

$B_{t}=$ Primary balance, which can be a primary deficit $\left(B_{t}>0\right)$ or a

primary surplus $\left(B_{t}<0\right)$.

$b_{t}=$ Primary balance in $t$, as a ratio of GDP.

$D_{t}=$ Debt at the end of period $t$.

$d_{t}=$ Debt at the end of period $t$, as a ratio of GDP.

$\pi_{t}=$ Inflation rate in $t$.

$\gamma_{t}=$ Nominal GDP growth rate.

$g_{t}=$ Real GDP growth rate.

$i_{t}=$ Nominal interest rate in $t$.

$M_{t}=$ Money stock at the end of period $t$.

$s_{t}=$ Seigniorage in $t$.

$r_{t}=$ Real interest rate in $t$.

$P_{t}=$ Price level in $t$.

$Y_{t}=$ Real GDP in $t$.

$m_{t}=$ Real money stock at the end of period $t$.

$A_{t}=$ Principal payments on outstanding debt at the end of period $t$.

how much a government must pay on its debt), outlays, and declines in tax receipts tend to increase a country's debt.

In other words, the annual government budget constraint can be written as

$$
\begin{gathered}
D_{t}=\left(1+i_{t}\right) D_{t-1}+B_{t}-\Delta M_{t} \\
=\underbrace{D_{t-1}}_{\text {Pre-existing Debt }}+\underbrace{\left(B_{t}+i_{t} D_{t-1}\right)}_{\text {Overall Balance }}-\underbrace{\Delta M_{t}}_{\text {Seigniorage }},
\end{gathered}
$$

where $\left(B_{t}+i_{t} D_{t-1}\right)$ is the overall balance-that is, the government deficit (if positive) or surplus (if negative) accounting for interest payments on existing debt. A surplus reduces the outstanding debt while a deficit increases $D_{t}$. Importantly, there are various options in choosing the empirical measure of the interest rate, $i_{t}$. The interest paid in $t$ over the pre-existing debt $\left(D_{t-1}\right)$ is largely predetermined as the nominal interest on Treasury bills and bonds determined at the time of issuance. This interest is sometimes indexed to inflation but usually is not affected by changes in interest rates on new issuance of debt during $t$. The ratio of total interest paid in $t$ over the existing debt is "effective interest." In practice, $i_{t}$ should be a weighted average of interest rates on the many individual securities that comprise the total outstanding debt $\left(D_{t-1}\right)$. In fact, 


\section{Table 1}

\section{Maturity Distribution and Average Length of Marketable Interest-Bearing Public Debt Held by Private Investors in 2011}

\begin{tabular}{|c|c|c|c|c|c|c|}
\hline \multicolumn{6}{|c|}{ Maturity } & \multirow[b]{2}{*}{$\begin{array}{l}\text { Amount outstanding } \\
\text { privately held }\end{array}$} \\
\hline Within 1 year & $1-5$ years & $5-10$ years & $10-20$ years & 20 years & $\begin{array}{l}\text { Average length } \\
\text { (months) }\end{array}$ & \\
\hline $2,503,926$ & $3,084,882$ & $1,543,847$ & 309,151 & 509,559 & 60 & $7,951,366$ \\
\hline
\end{tabular}

NOTE: Amounts are listed in millions of U.S. dollars.

SOURCE: Office of Debt Management, Office of the Under Secretary for Domestic Finance, Treasury Bulletin, December 2011.

total outstanding debt is itself composed of various types of bonds, bills, and notes with different features, maturities, and interest rates. Table 1 breaks down the total outstanding U.S. debt in 2011 by maturity brackets.

The structure of government debt is biased toward shorter maturities, as Table 1 clearly shows. This choice is explained in part by the fact that shorter-maturity debt normally carries lower interest rates, and rolling over short-term debt is cheaper than issuing longer-term debt. As for companies, when the average maturity of debt is short, it is more likely that an adverse interest rate increase (due to either monetary developments or perceived riskiness of the sovereign) will be required to refinance the debt at rollover. This explains why an alternative measure of the nominal interest rate (at $t$ ) is the current yield rate on bonds with maturities close to the duration of the outstanding debt. Theoretically, such a rate would apply if all existing debt were amortized and reissued with a maturity equal to the duration of the debt. Define $A_{t}$ as the amount of principal payments (or amortization) at time $t$. Abstracting from changes in $M_{t}$, then, debt service in $t$ is the sum of debt amortization $A_{t}$ and interest payments, $i_{t} D_{t-1}$. In every period, current debt can be divided into existing debt and new debt:

$$
D_{t}=\underbrace{D_{t-1}-A_{t}}_{\text {Pre-existing Debt }}+\underbrace{A_{t}+i_{t} D_{t-1}+B_{t}}_{\text {New Debt }} .
$$

This equation is important for understanding the rollover risk implied by maintaining a short maturity structure. Suppose that all debt is amortized in every period and is rolled over $\left(A_{t}=D_{t-1}\right)$. Then the new debt will carry a new interest rate for each of the maturities in which the new debt is issued in $t$. If debt subscribers require a higher return, perhaps because the perceived riskiness of the country has increased, then the entire debt will be more expensive to service in the future. Therefore, countries tend to issue bills and bonds with various maturities to reduce the risks implied by debt rollover. As Figure 1 shows, the weighted average maturity for all 10 countries considered is quite heterogeneous: Some countries tend to have a larger share of shorter-term debt and others tend to favor longer-maturity issuances.

To relate these variables to the size of the economy, consider taking the ratio of debt $\left(D_{t}\right)$ to nominal GDP $\left(P_{t} Y_{t}\right)$ and reorganizing the equation as follows: 


\section{Contessi}

\section{Figure 1}

Weighted Average Maturity of Government Debt for 10 Countries (as of December 31, 2011)

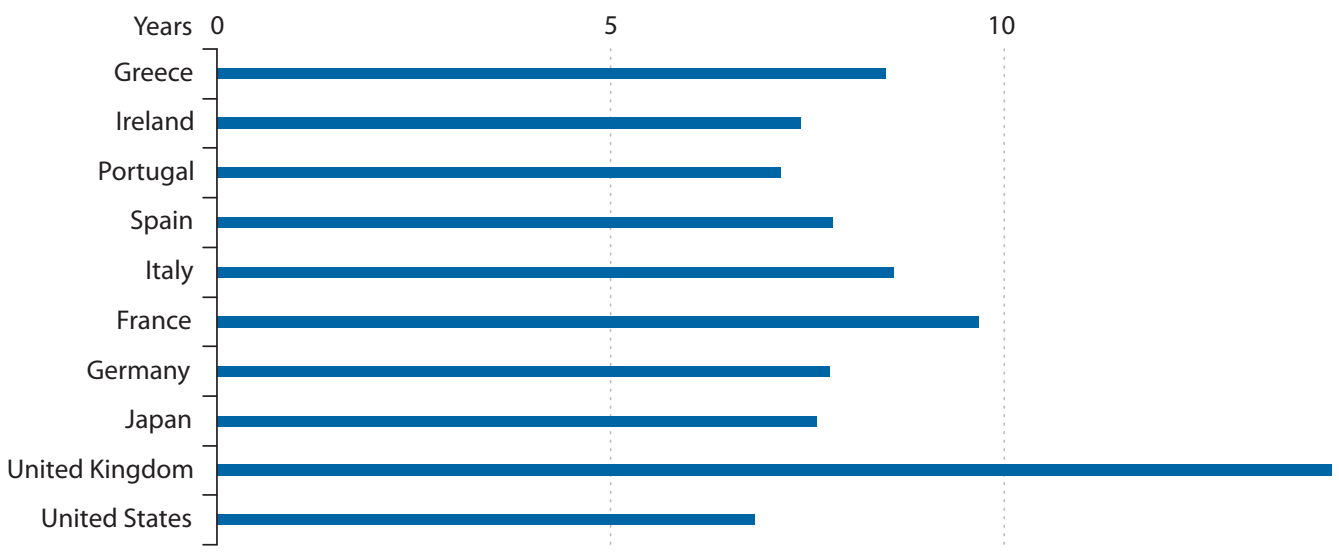

$$
\begin{aligned}
& \frac{D_{t}}{P_{t} Y_{t}}=\frac{\left(1+i_{t}\right) D_{t-1}}{P_{t} Y_{t}}+\frac{B_{t}}{P_{t} Y_{t}}-\frac{\Delta M_{t}}{P_{t} Y_{t}} \\
& =\left(1+i_{t}\right) \frac{P_{t-1} Y_{t-1}}{P_{t-1} Y_{t-1}} \frac{D_{t-1}}{P_{t} Y_{t}}+\frac{B_{t}}{P_{t} Y_{t}} s_{t} \\
& =\frac{\left(1+i_{t}\right)}{\left(1+g_{t}\right)\left(1+\pi_{t}\right)} d_{t-1}+b_{t}-s_{t},
\end{aligned}
$$

where $s_{t}=\frac{\Delta M_{t}}{P_{t} Y_{t}}$ denotes seigniorage in real terms. To rearrange this ratio we use the fact that the nominal growth rate of GDP $\left(\gamma_{t}\right)$ can be decomposed into a real component whose growth rate is $g_{t}$ and a price component whose growth rate (inflation) is $\pi_{t}$ :

$$
\left(1+g_{t}\right)\left(1+\pi_{t}\right)=\left(1+\gamma_{t}\right)
$$

Similarly, the nominal interest rate can be decomposed into a real component $\left(r_{t}\right)$ and inflation:

$$
\left(1+r_{t}\right)\left(1+\pi_{t}\right)=\left(1+i_{t}\right)
$$

Under the assumption that both $i_{t}$ and $\pi_{t}$ are small, $r_{t} \cong i_{t}-\pi_{t}$ when the real interest rate is approximated as $r_{t} \cong \frac{\left(i_{t}-\pi_{t}\right)}{\left(1+\pi_{t}\right)}$ and equation (7) becomes

$$
d_{t}=\underbrace{\frac{\left(1+r_{t}\right)}{\left(1+g_{t}\right)}}_{\varphi_{t}} d_{t-1}+b_{t}-s_{t},
$$


where $d_{t} \equiv D_{t} / P_{t} Y_{t}$ and $\varphi_{t}$ is sometimes called the "discount factor." Equation (10) is derived from accounting identities and always holds ex post, because one way or another the left-hand side equals the right-hand side. Although the following analysis assumes $s_{t}=0$, the appendix discusses a common interpretation of seigniorage. Equation (10) can be solved recursively as follows:

$$
\begin{aligned}
d_{1} & =\varphi_{1} d_{0}+b_{1} \\
d_{2} & =\varphi_{2} d_{1}+b_{2} \\
& =\varphi_{2}\left[\varphi_{1} d_{0}+b_{1}\right]+b_{2} \\
& =\varphi_{2} \varphi_{1} d_{0}+\varphi_{2} b_{1}+b_{2} \\
d_{3} & =\varphi_{3} \varphi_{2} \varphi_{1} d_{0}+\varphi_{3} \varphi_{2} b_{1}+\varphi_{3} b_{2}+b_{3} \\
d_{4} & =\ldots
\end{aligned}
$$

to obtain

$$
d_{t}=d_{o} \prod_{i=1}^{t} \varphi_{i}+\sum_{i=1}^{t} b_{i} \prod_{j=i+1}^{t} \varphi_{j}
$$

If equation (11) is used in forward-looking analysis, it is customary-although not realistic - to assume constant balances and discount factors, which can be interpreted as averages:

$$
d_{t}=d_{o} \varphi^{t}+b \sum_{i=0}^{t-1} \varphi^{i}
$$

This equation can be used for various exercises-for example, to calculate the size of net borrowing necessary to reach a target debt-to-GDP ratio starting from certain initial conditions (see the next section).

Equation (10) also allows comparison of cases when debt-to-GDP ratios are explosive versus when they are sustainable. The key variable is $\varphi_{t}=\frac{\left(1+r_{t}\right)}{\left(1+g_{t}\right)} ; \varphi_{t}$ is greater than 1 when the real interest rate is larger than the growth rate of GDP. Ceteris paribus, the debt-to-GDP ratio will continuously increase unless the overall balance $(b)$ is large enough to counterbalance the interestgrowth differential. One way a government can achieve this result is to persistently run large enough primary surpluses, or even small enough deficits.

Figures 2 and 3 show graphs for sustainable and unsustainable debt situations, respectively. These graphs also represent a simple way to describe equation (10) as a linear difference equation. In difference equations, the past value of a state variable determines its future values. The solution to a difference equation conveys the value of the state variable (in this case, the debt-toGDP ratio) at each point in time.

The evolution of the debt-to-GDP ratio can be illustrated graphically. The outer horizontal and vertical lines represent the level of debt to GDP in each $t-1$ and $t$ period, respectively. Along the 45-degree dashed line, $d_{t+1}=d_{t}$, the debt-to-GDP ratio is not changing or is in steady state. The continuous line represents the evolution of the debt ratio. For any current level of debt $\left(d_{t}\right)$ on the horizontal axis, the height of the line is the debt in the next period $\left(d_{t+1}\right)$. Thus, given an initial level $d_{0}$ of the debt-to-GDP ratio (similar in Figures 2 and 3), its evolution over time in this economy can be easily traced. The list of values taken over time is the solution of equation (10). 


\section{Contessi}

Figure 2

Debt Dynamics When Debt Is Sustainable

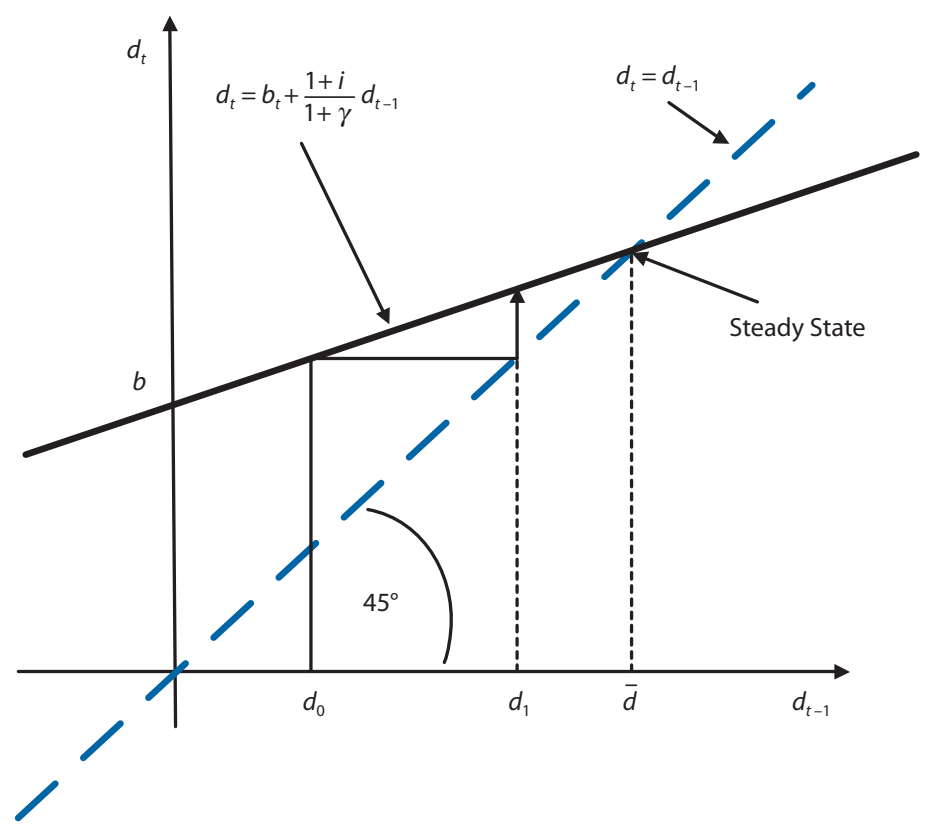

\section{Figure 3}

\section{Debt Dynamics When Debt Is Unsustainable}

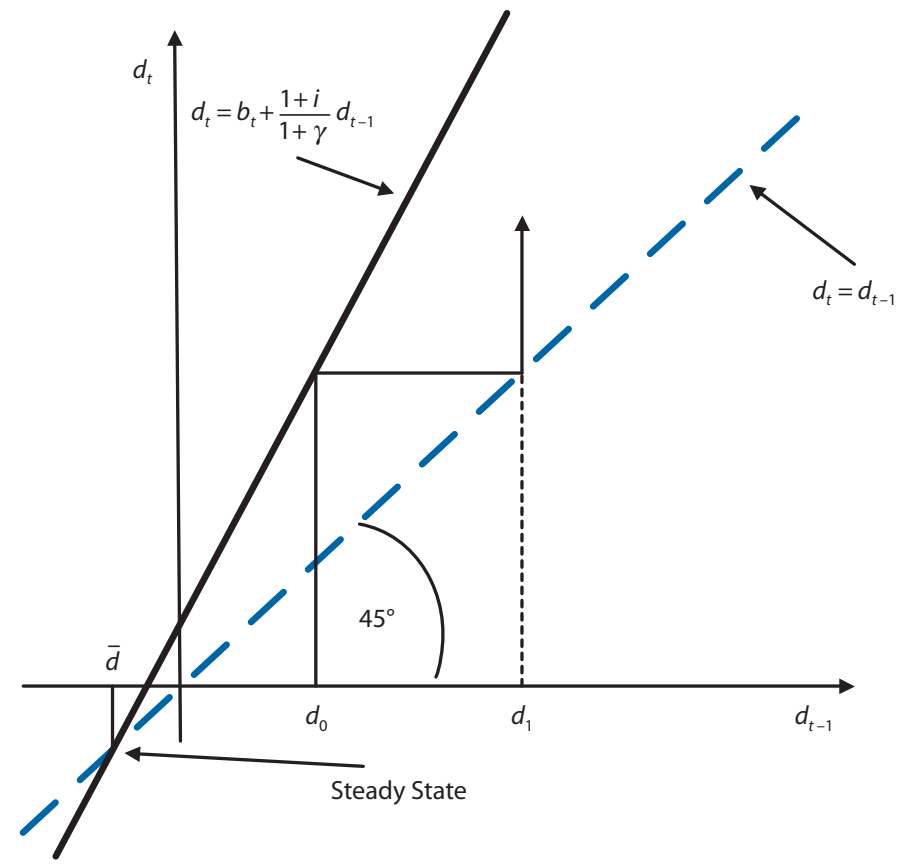




\section{Figure 4}

\section{Real GDP Growth (2003-12)}
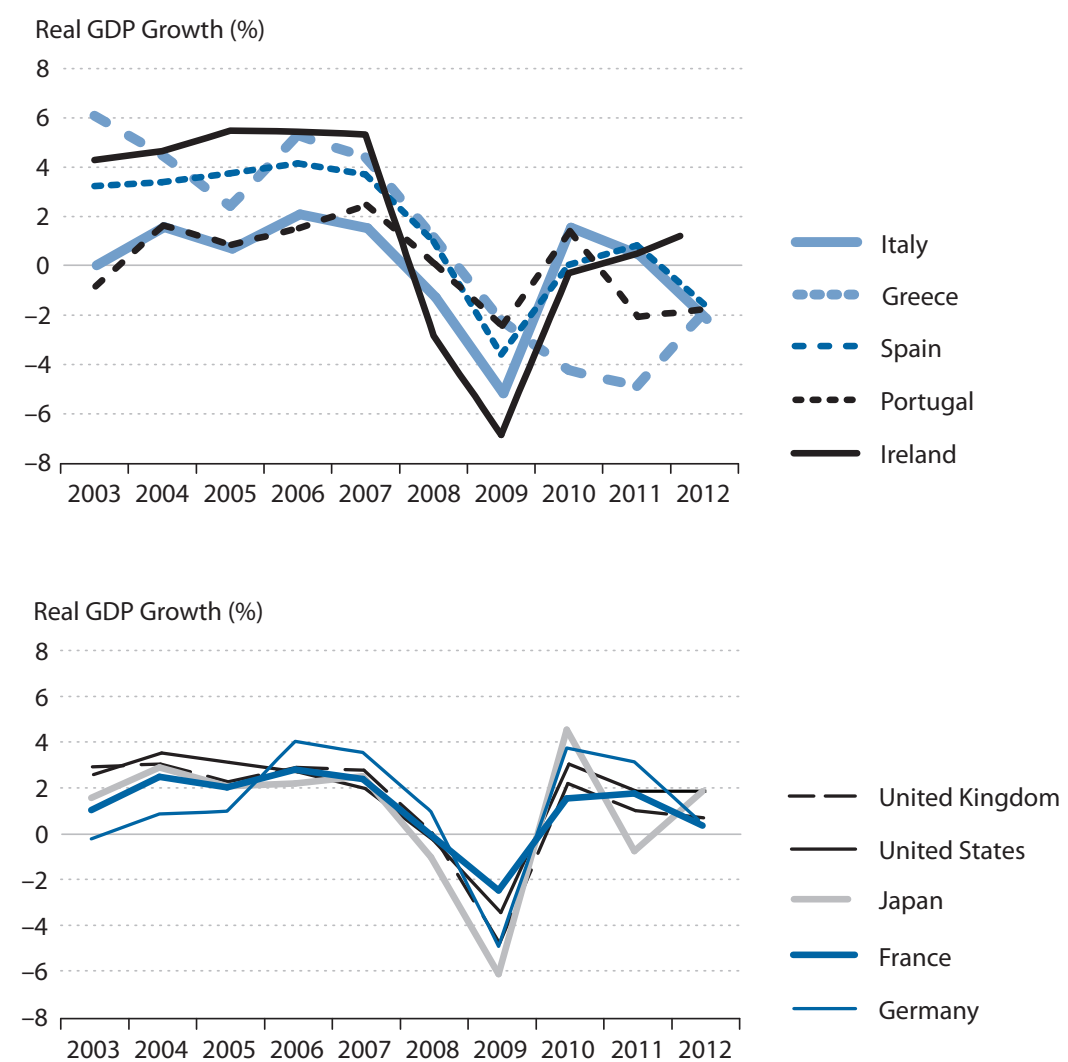

NOTE: Data for 2011 and 2012 are projections.

SOURCE: World Economic Database, International Monetary Fund, January 2012.

Note that in Figure 2 the debt-to-GDP ratio gradually approaches the steady-state locus and then stabilizes at the crossing of the 45-degree line and the equation describing $d_{t}$, whereas in Figure 3 it diverges from it and therefore is considered explosive. The two graphs represent cases in which $\varphi_{t}$ is smaller and greater than 1 . For a given level of the annual deficit (the intercept on the vertical axis obtained by imposing $d_{t-1}=0$ ), the debt will continue to grow indefinitely if $\varphi_{i}$ $>1$, or in other words, if the interest rate is larger than the growth rate of the economy $\left(r_{t}>g_{t}\right)$. In the opposite case, $r_{t}<g_{t}$, the debt-to-GDP ratio grows at a slower pace up to the point where $d_{t}=d_{t-1}$, after which it will stop growing. The level of steady-state debt can be calculated by imposing $d_{t-1}=d_{t}=\bar{d}$, which gives $\bar{d}=b_{t} /\left(1-\varphi_{t}\right)$. This equation also suggests how primary surpluses can help to control debt dynamics: A less negative primary surplus shifts the continuous line down so that the intercept is lower, making it easier for the government to sustain a certain level of debt to GDP.

The analysis in this section can be extended in many directions; one is the case of government debt issued in foreign currencies. The case of the troubled European countries could be 


\section{Contessi}

\section{Figure 5}

\section{Evolution of Overall and Primary Balances (2007-12)}
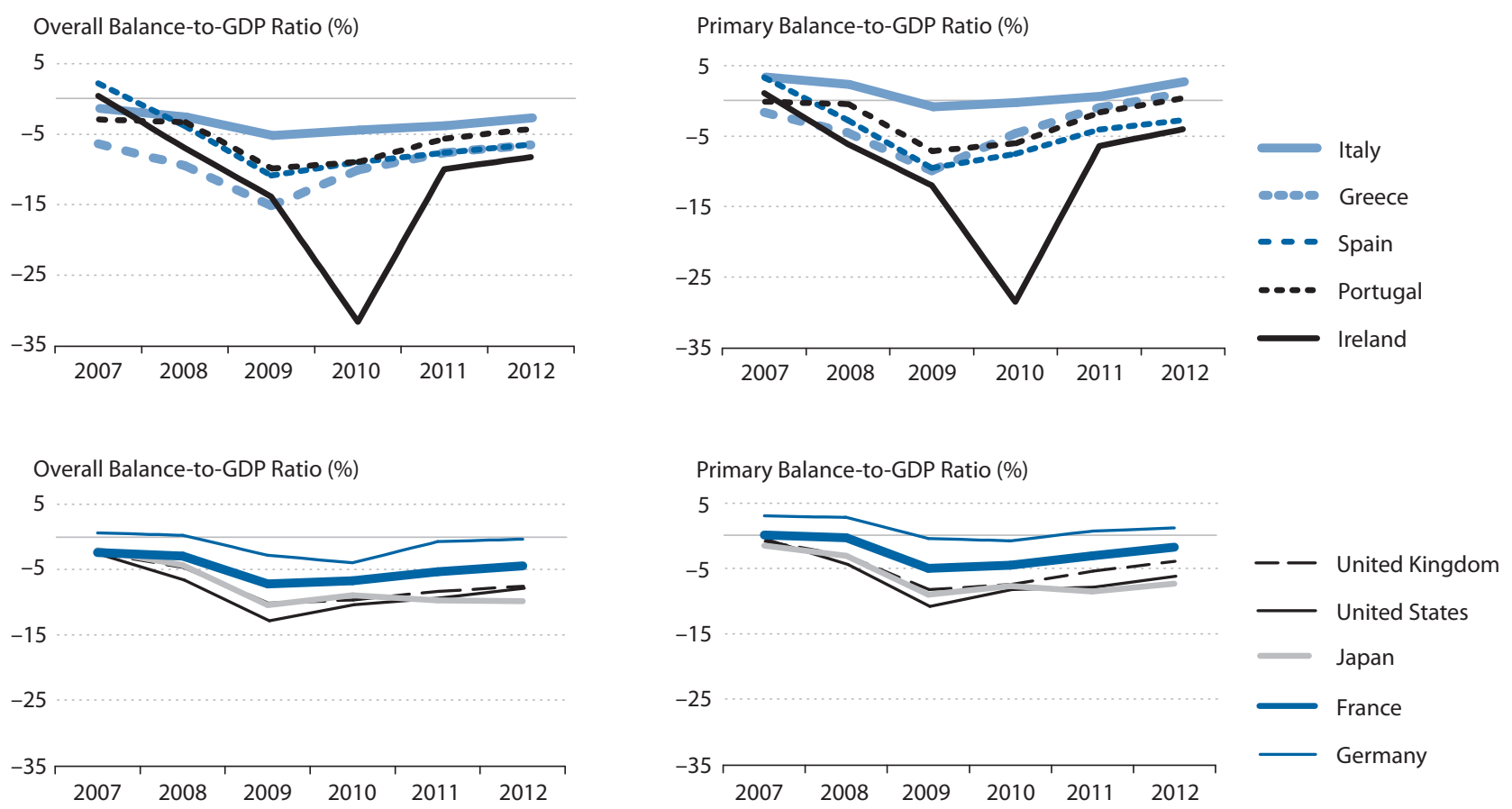

NOTE: Data for 2011 and 2012 are projections.

SOURCE: Fiscal Monitor database, International Monetary Fund, January 2012.

considered within such a framework if the euro were considered as a foreign currency, but this analysis is beyond the scope of this article. Boone and Johnson $(2011,2012)$ and Bergsten and Kirkegaard (2012) offer an analysis of problems specific to the euro zone.

\section{DEFICIT AND DEBT DYNAMICS IN THE WAKE OF THE FINANCIAL CRISIS OF 2007-09}

The increase of public debt is a recurring feature of the aftermath of financial and banking crises (Reinhart and Rogoff, 2009). In fact, the global recession of 2008-09 contributed to large increases in annual deficits and debt-to-GDP ratios in all advanced economies.

Consider the evolution of GDP and government finances in the five peripheral EU countries and five of the remaining G-7 countries (the United States, France, the United Kingdom, Germany, and Japan) as shown in Figures 4 to 6. 6 Figure 4 plots the real GDP growth for the 10 economies, Figure 5 plots overall balances $\left(B_{t}+i_{t} D_{t-1}\right)$ and primary balances $\left(B_{t}\right)$, and Figure 6 plots projected gross $\left(D_{t}\right)$ and net government debt for 2007-12. The variables for the plots are normalized by the GDP of each country for the corresponding period.

The synchronous nature of the global recession is evident from Figure 4: These countries experienced a sharp, large, and almost simultaneous drop of GDP between the end of 2008 and 


\section{Figure 6}

\section{Evolution of General Gross and Net Government Debts (2007-12)}
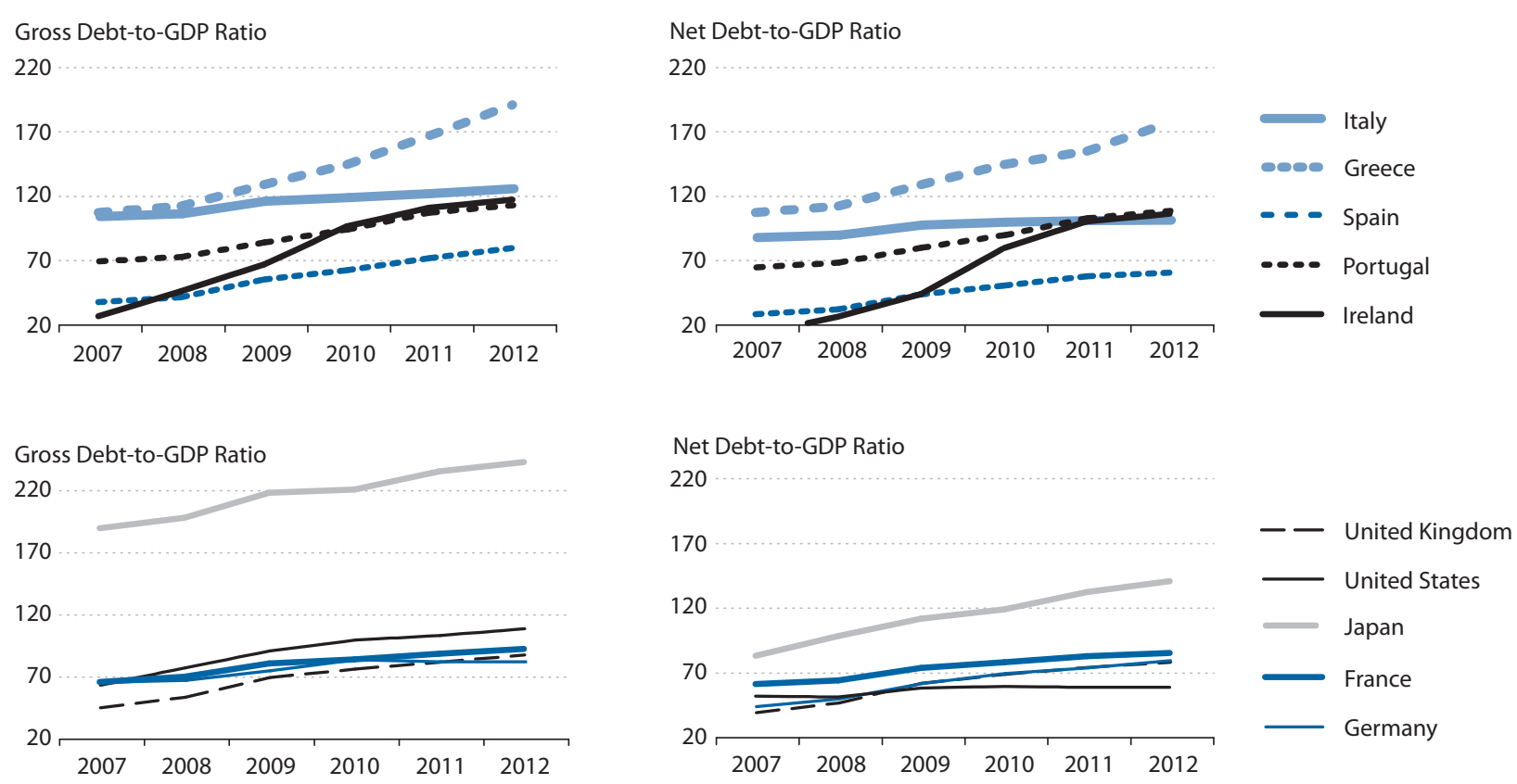

NOTE: Data for 2011 and 2012 are projections.

SOURCE: Fiscal Monitor database, International Monetary Fund, January 2012.

the beginning of 2009. This drop was large by historical standards-second only to the Great Depression (see also Imbs, 2010). The aftermaths of these large recessions in individual economies were consistent with the experiences of other crises, as documented by Reinhart and Rogoff (2009) and Laeven and Valencia (2008). First, many countries adopted expansive fiscal policies to counteract the effects of national recessions. Second, some countries either nationalized part of their banking systems or provided capital injections to banks, which ultimately aggravated their annual deficits.

What effect did these policies have on debt? Comparing the most recent data on debt in 2011 with 2007 shows that the debt-to-GDP ratios grew by an average 112.4 percent in the five peripheral EU countries and by 46.6 percent in the other five advanced G-7 economies. The peripheral EU countries definitely experienced a larger growth of debt on average but with great disparities: The Italian debt-to-GDP ratio grew by only 17 percent compared with a stunning 337 percent growth of the Irish debt-to-GDP ratio. Clearly, such increases in debt levels imply additional costs in terms of interest rates on the stock of outstanding debt, the consequences of which may not have been fully anticipated when short-term fiscal stabilization measures were taken (see Bullard, 2012). As a result of the accompanying expansionary monetary policy, interest rates in the immediate aftermath of the recession have been favorably low in the sense that new debt issuances have carried relatively low interest rates in most countries. However, even without tensions on sovereign debts, the recovery of the global economy may be accompanied 


\section{Contessi}

\section{Figure 7}

\section{Projected Debt-to-GDP and Deficit-to-GDP Ratio Pairs (2007-12)}

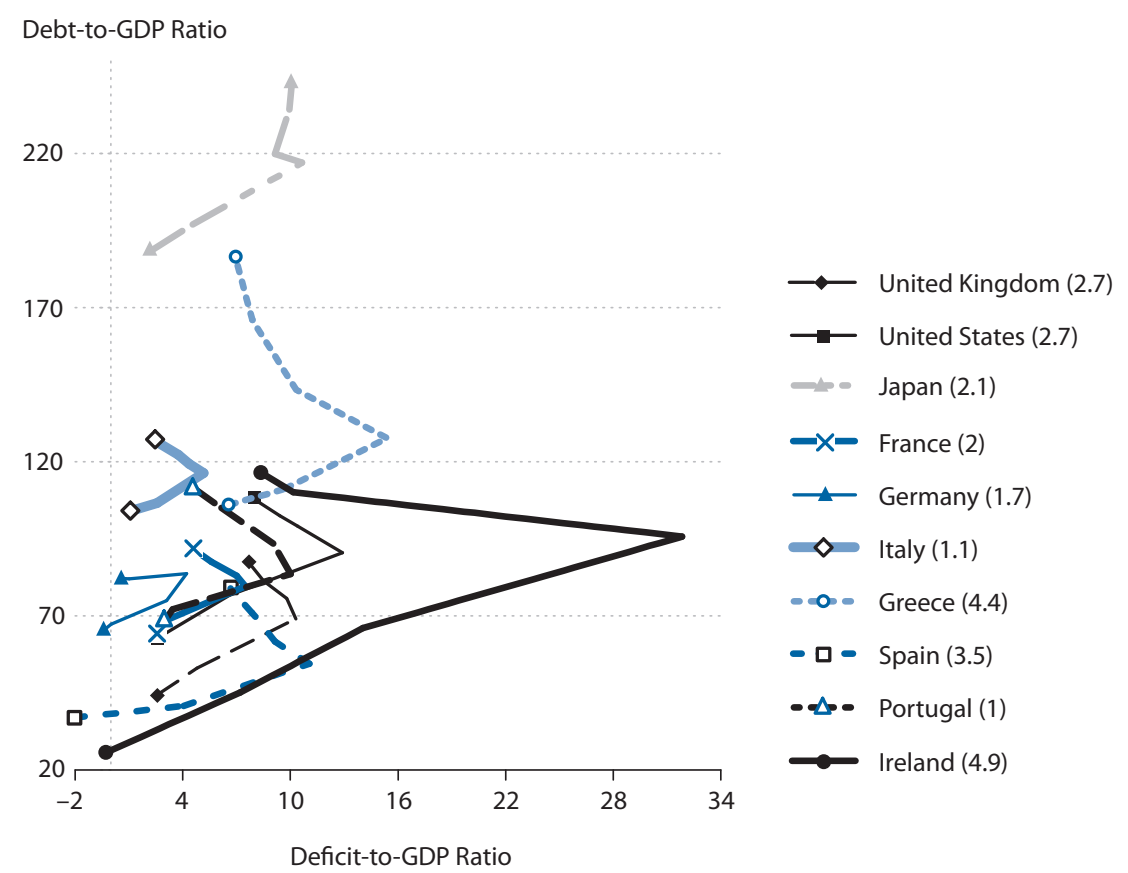

NOTE: Data for 2012 are projections. Data in parentheses indicate the average real GDP growth rate (percent) over 2003-07. SOURCE: Fiscal Monitor database, International Monetary Fund, January 2012.

by a less expansionary monetary policy in the medium term, implying likely increases in interest rates. Given the increase in debt-to-GDP ratios in many countries, such a scenario is likely to carry the additional burden of higher interest rates, even for countries whose sustainability of public debt is not questioned. As higher interest rates on debt create pressure on overall balances, national debt in some countries may be perceived as less sustainable.

Figure 7 plots pairs of debt-to-GDP and deficit-to-GDP ratios for all 10 economies for the period between 2007 and 2012. Figure 8 breaks the time path for these countries as follows: The pairs of variables plotted on the left-hand side are for the period between 2007 and 2009 (i.e., through the peak of the crisis); the graph on the right-hand side of this figure shows the recovery period (2009-11). The average GDP growth rate over 2003-07 is listed in parentheses after the country names.

Figure 8 reveals four facts: First, all 10 advanced economies experienced a similar trend during the crisis. Deficit-to-GDP ratios markedly expanded through the peak of the crisis in 2008-09 in response to lower tax revenues, higher expenditure because of fiscal policy interventions and automatic stabilizers, and contracting output (at the denominator). Second, the response is heterogeneous for individual countries through the peak of the crisis: Some countries generated huge deficits (e.g., Ireland) and some countries maintained fairly small overall balances (e.g., Italy). Third, there was an almost uniform rebound of deficits during the 2009-11 


\section{Figure 8}

\section{Debt-to-GDP and Deficit-to-GDP Ratio Pairs through the Recession (left) and Recovery (right)}

2007-09

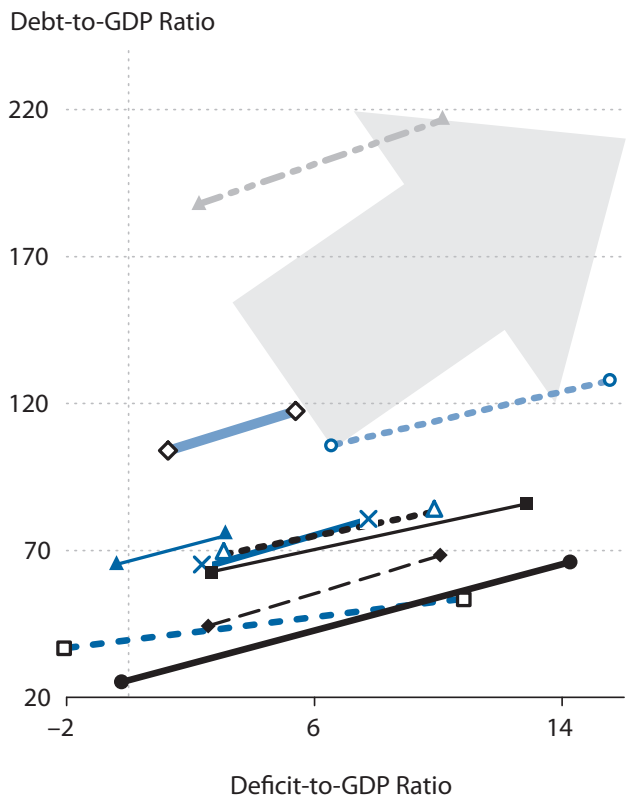

2009-11

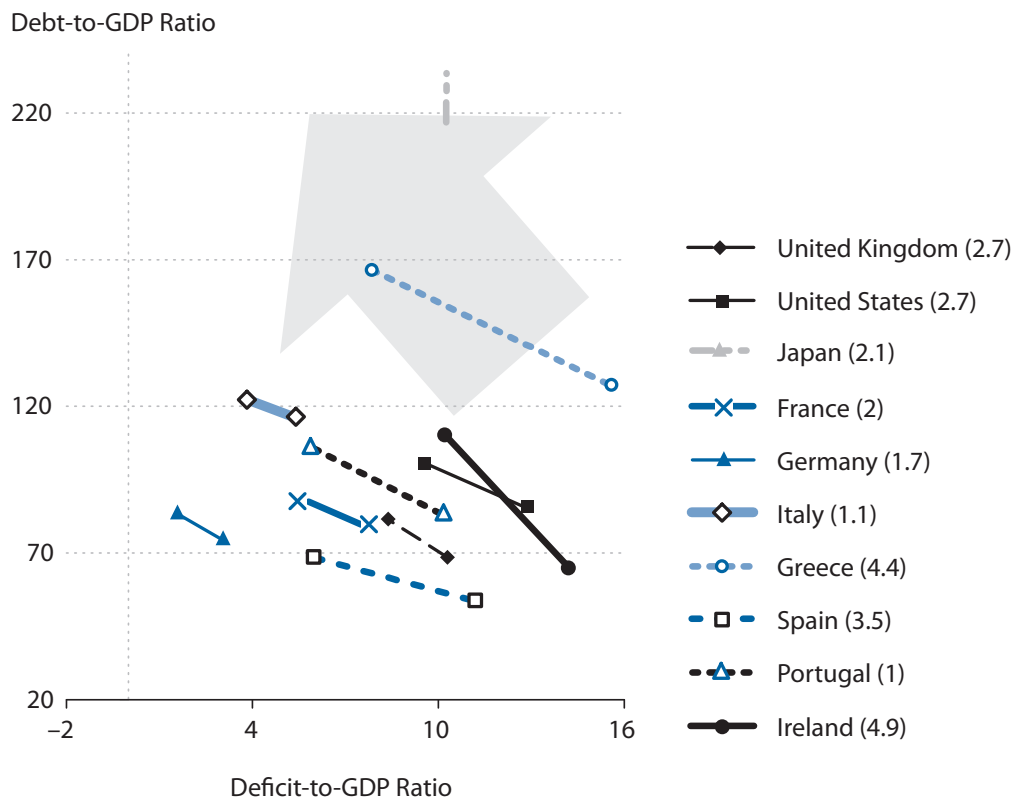

NOTE: Data in parentheses indicate the average real GDP growth rate (percent) over 2003-07.

SOURCE: Fiscal Monitor database, International Monetary Fund, January 2012.

period as most countries reverted to "normal mode" both in terms of GDP and their annual deficit; this rebound curbed the debt-to-GDP growth but in no country did it reduce total debt. Finally, the rebound effects were also very heterogeneous: Some countries are enforcing strict fiscal discipline and some are accumulating even more debt through large deficits.

How should these observations be interpreted in light of our previous discussion on the arithmetic of government debt sustainability? Although the rising debt-to-GDP ratios of the five peripheral EU countries particularly concern investors, Figures 7 and 8 clearly show that fiscal pressures are not unique to this group. All five peripheral EU countries face burdensome public debt and budget deficits, but the causes for uncertainty in each country's situation differ. As noted, Italy had the smallest increase in debt but its economy was characterized by a large initial stock of debt and poor expected growth. Although Ireland and Spain had much lower debt before the turmoil began in 2007, they experienced very large deficit increases. Portugal had moderate debt but also experienced sizable deficit increases and its growth history and projections are quite poor. Finally, the most troubled country, Greece, had both a large pre-crisis debt and a ballooning deficit. Table 2 lists other relevant indicators that characterize the situation of each country. Other elements not captured by previous equations matter to determine the perceived debt sustainability but are somewhat more difficult to quantify: All peripheral countries except Ireland share a high share of government expenditure as a percentage of GDP, 


\section{Contessi}

\section{Table 2}

\section{Selected Indicators for a Group of Advanced Economics}

\begin{tabular}{|c|c|c|c|c|c|}
\hline \multirow[b]{2}{*}{ Indicator } & \multicolumn{5}{|c|}{ Peripheral European countries } \\
\hline & Greece & Ireland & Portugal & Spain & Italy \\
\hline $\begin{array}{l}\text { Real GDP growth } \\
\text { (\%; average 2003-07) }\end{array}$ & 4.34 & 5.32 & 0.98 & 3.52 & 1.14 \\
\hline \multicolumn{6}{|l|}{ Debt-to-GDP ratio } \\
\hline 2007 & 105.4 & 24.9 & 68.3 & 36.1 & 103.6 \\
\hline 2011 & 165.6 & 109.3 & 106.0 & 70.1 & 121.4 \\
\hline Growth rate during 2007-11 (\%) & 57.1 & 338.2 & 55.3 & 94.1 & 17.2 \\
\hline \multicolumn{6}{|l|}{ Deficit-to-GDP ratio } \\
\hline 2007 & 6.7 & -0.1 & 3.2 & -1.9 & 1.5 \\
\hline 2011 & 8.0 & 10.3 & 5.9 & 8.0 & 3.9 \\
\hline \multicolumn{6}{|l|}{ Government size } \\
\hline $\begin{array}{l}\text { General government expenditures } \\
\text { (\% of GDP, 2008) }\end{array}$ & 48.3 & 42 & 46 & 41.1 & 48.7 \\
\hline $\begin{array}{l}\text { Public pensions pending } \\
\text { (\% of GDP, 2005) }\end{array}$ & 11.5 & 3.4 & 10.2 & 8.1 & 14 \\
\hline $\begin{array}{l}\text { Projected changes in age-related } \\
\text { public expenditure in pensions } \\
\text { between } 2004 \text { and } 2030 \text { ( } \% \text { of GDP) }\end{array}$ & NA & 3.1 & 4.9 & 3.3 & 0.8 \\
\hline \multicolumn{6}{|l|}{ Shadow economy } \\
\hline $\begin{array}{l}\text { Shadow economy } \\
\text { (\% of GDP, 2006) }\end{array}$ & 26 & 14.5 & 20.4 & 20.2 & 23.1 \\
\hline \multicolumn{6}{|c|}{$\begin{array}{l}\text { Main parameters of public pension } \\
\text { schemes for employees in the private sector }\end{array}$} \\
\hline $\begin{array}{l}\text { Statutory retirement age } \\
\text { (years) (men/women) }\end{array}$ & 65 & 65 & 65 & 65 & $65 / 60$ \\
\hline $\begin{array}{l}\text { Contribution period for full pension } \\
\text { (years) }\end{array}$ & 35 & & 40 & 35 & NA \\
\hline Reference period for benefits & Last 5 years & & Career & Best 15 years & Career \\
\hline Average benefit accrual rate & 2.57 & & $2.00-2.30$ & 2.9 & 1.75 \\
\hline Average pension level* & 93.6 & 34.2 & 53.6 & 73 & 69.3 \\
\hline $\begin{array}{l}\text { Average pension wealth } \\
\text { (men/women) }^{+}\end{array}$ & $14.2 / 16.5$ & $6.1 / 7.2$ & $8.1 / 9.5$ & $12.0 / 14.0$ & $10.0 / 10.8$ \\
\hline Indexation of benefits $\ddagger$ & Discretionary & & Adjusted prices & Prices & Prices \\
\hline Fertility rate (2008) & 1.51 & 2.1 & 1.37 & 1.46 & 1.41 \\
\hline
\end{tabular}

NOTE: *Pension level as a percentage of economy-wide average earnings; ${ }^{\dagger}$ pension wealth as a multiple of economy-wide average earnings; FGDP growth is also taken into account in the indexation of benefits.

SOURCE: a, International Monetary Fund (IMF), World Economic Outlook database, 2010. b, European Commission, Office of Management and Budget, European Central Bank, Financial Stability Review 2010; IMF, World Economic Outlook Database, 2010. c, Organisation for Economic Co-operation and Development (OECD), Factbook 2010: Economic, Environmental and Social Statistics, 2010. d, OECD, Pensions at a Glance, 2009. e, European Commission, European Economy: Long-Term Sustainability of Public Finances in the European Union (Publication No. 4/2006), 2006. f, Buehn and Schneider (2007; version 2, pp. 1-53). g, World Bank, World Development Indicators; http://data.worldbank.org/indicator/SP.DYN.TFRT.IN. 
Selected advanced economies

\begin{tabular}{|c|c|c|c|c|c|}
\hline France & Germany & Japan & U.K. & U.S. & Sources \\
\hline 2.00 & 1.48 & 2.08 & 2.70 & 2.80 & a \\
\hline 64.2 & 65.0 & 187.7 & 43.9 & 62.3 & $a, b$ \\
\hline 87.0 & 81.5 & 233.4 & 80.8 & 102.0 & $a, b$ \\
\hline 35.5 & 25.4 & 24.4 & 83.9 & 63.6 & \\
\hline 2.8 & -0.3 & 2.4 & 2.7 & 2.7 & a \\
\hline 5.7 & 1.1 & 10.1 & 8.6 & 9.5 & \\
\hline 52.7 & 43.8 & 37.1 & 47.5 & 38.8 & c \\
\hline 12.4 & 11.4 & 8.7 & 5.7 & 6 & $d$ \\
\hline 1.5 & 0.9 & NA & 1.3 & NA & e \\
\hline 13.2 & 15.4 & 8.9 & 10.9 & 8 & $f$ \\
\hline 60 & 65 & 65 & 65 & 67 & $d$ \\
\hline 40 & NA & 40 & 44 & 35 & $d$ \\
\hline Best 25 years & Career & Career & Career & Best 35 years & $d$ \\
\hline & 1 & 0.55 & Flat rate & $\approx 1.2$ & $d$ \\
\hline 51.2 & 40.5 & 33.5 & 28.9 & 37.1 & $d$ \\
\hline $9.5 / 11.0$ & $7.8 / 8.3$ & $6.0 / 6.8$ & $4.7 / 5.4$ & $5.9 / 6.8$ & $d$ \\
\hline Prices & Wage & Prices & Prices & Prices & $d$ \\
\hline 2 & 1.38 & 1.34 & 1.94 & 2.1 & $g$ \\
\hline
\end{tabular}




\section{Contessi}

low fertility rates (with fewer future workers to reduce the debt), and a large informal economy that makes tax revenues collection arduous.

In addition, the liabilities of the countries' pension systems are a major concern: Four of the five countries (Ireland is an exception) currently spend (or are projected to spend) a larger share of their GDP to pay for public pensions relative to other advanced economies (see Table 2).

\section{Debt Sustainability}

We can now use these data and some results in the second section to discuss the impact of the crisis on debt sustainability. In particular, we can start with the initial conditions in 2011 and use equation (12) to calculate the size of net borrowing necessary to reach a certain debt-to-GDP ratio within a certain number of years:

$$
d_{t}=d_{o} \varphi^{t}+b \sum_{i=0}^{t-1} \varphi^{i}
$$

As an example, we consider two countries, such as Ireland and Portugal, with similar $d_{o}=d_{2011}$ of 1.1 and a real interest rate $\left(r_{t}\right)$ of 1 percent, but very different expected real GDP growth $\left(g_{t}\right)$. Imagine that both countries have a target debt-to-GDP ratio of $\bar{d}=60$ percent (as required by the Maastricht treaty) to be reached in 20 years (this choice is arbitrary). Moreover, let us assume that the pre-crisis (2003-07) average GDP growth rate is a good predictor of future growth and consider $g_{2003-07}^{\text {Ireland }}=4.9$ percent and $g_{2003-07}^{\text {Portugal }}=1$ percent.

Because $\varphi_{2003-07}^{\text {Ireland }}=0.96$ and $\varphi_{2003-07}^{\text {Portugal }}=1$, we have

$$
\begin{aligned}
& b_{2003-07}^{\text {Ireland }}=\frac{-1.1(0.96)^{20}+0.6}{\sum_{i=0}^{19}(0.96)^{i}} \\
& b_{2003-07}^{\text {Portugal }}=\frac{-1.1(1)^{20}+0.6}{\sum_{i=0}^{19}(1)^{i}} .
\end{aligned}
$$

Solving for $b_{2003-07}^{\text {Ireland }}$ and $b_{2003-07}^{\text {Portugal }}$ for the two countries yields very different target surpluses. Under the assumptions made so far, our rough calculations suggest that lowering the debt-toGDP ratio from 1.1 to 0.6 in 20 years would allow Ireland to generate annual surpluses of 0.59 percent of GDP and Portugal would need to generate a large annual surplus of 2.5 percent of GDP; in this calculation, the difference is purely due to the diverse growth rate of GDP. (Note that these calculations are made under the assumptions that pre-crisis real GDP growth rates are a good predictor of future growth.)

The analysis in the second section allows consideration of the sustainability of debt-toGDP ratios. Consider equation (10) and take a period-to-period difference:

$$
d_{t}-d_{t-1}=\frac{r_{t}-g_{t}}{1+g_{t}} d_{t-1}+b_{t}
$$

In order to stabilize the debt-to-GDP ratio $\left(d_{t}=d_{t-1}\right)$, the primary balance should be 


$$
b_{t}^{*}=\frac{g_{t}-r_{t}}{1+g_{t}} d_{t-1} .
$$

Therefore, any primary balance lower than $b_{t}^{*}$ will reduce the debt-to-GDP ratio. The ease with which a government can reduce $d_{t}$ depends on the interest-growth differential. The larger the $r_{t}-g_{t}$ spread, the more difficult it is to reduce debt. If interest rates and growth rates are approximately the same, then a small primary balance is sufficient to keep the debt stable.

Considering the transformation between the nominal and real rates, $\underline{7}$

$$
\frac{r_{t}}{1+g_{t}}=\frac{i_{t}-\pi_{t}}{1+\gamma_{t}}
$$

Then equation (16) can be transformed into

$$
d_{t}-d_{t-1}=\frac{i_{t}}{1+\gamma_{t}} d_{t-1}-\frac{\pi_{t}}{1+\gamma_{t}} d_{t-1}-\frac{g_{t}}{1+g_{t}} d_{t-1}+b_{t}
$$

The right-hand side of equation (17) can be interpreted as the impact on changes in the debt-to-GDP ratio from interest costs, inflation, real growth, and fiscal adjustment through changes in the primary balance (variations in revenues and non-interest spending). Naturally, the terms capturing the cost of interests and inflation are not independent, as equation (9) shows.

Equation (16) clarifies that inflation has an impact on the debt ratio only to the extent that it lowers the real interest rate paid by the government; two exceptions occur when past debt is indexed to inflation (or denominated in foreign currency) and future higher inflation is not anticipated. As euro area inflation rates are considered anchored to expectations thanks to the ECB monetary policy, unexpected higher inflation is unlikely - though not impossible-in the European peripheral countries. For the part of the debt that is indexed to inflation, changes in actual inflation translate one to one in changes in the nominal interest rate paid by individual governments.

Table 3 shows the calculated nominal interest-growth differential using effective interest rates and long-term interest rates (10-year treasury bonds when available) for three periods: a pre-crisis average for 2003-07, a crisis average for 2008-09, and a recovery average for 2010-11. The table provides a powerful partition of countries based on the relationship between the growth rate and the measure of the interest rate for each economy. Notice that we use both a measure of effective interest rates (total interest paid over outstanding debt) and a measure of long-term interest rates.

Table 3 shows that in the 2003-07 period the interest-growth differentials were either negative (implying sustainability in the long run) or mildly positive, but certainly quite close to zero. The situation reversed at the peak of the crisis in 2008-09 when all these differentials were large and positive due to the contraction of GDP. However, the 2010-11 recovery shows how the two groups of countries exited the crisis with quite different differentials: In particular, there are positive and large interest-growth differentials for the peripheral EU countries but either negative or close to zero differentials for the other five countries. A similar discrepancy is already evident when considering effective interest rates but is magnified when long-term interest rates, which are a better approximation of the cost of new debt issuances, are used as an empirical 


\section{Contessi}

Table 3

\section{Calculation of Nominal Interest-Growth Differentials for Three Periods}

\begin{tabular}{lccccc} 
GDP growth rate & Effective & Long-term & interest rate \\
Country & $(\%) \gamma_{t}$ & $(\%) i_{t}$ & $\begin{array}{c}\text { Difference } \\
(\%) i_{t}-\gamma_{t}\end{array}$ & $\begin{array}{c}\text { interest rate } \\
(\%) * i_{t}\end{array}$ & $\begin{array}{c}\text { Difference } \\
(\%) i_{t}-\gamma_{t}\end{array}$ \\
\hline
\end{tabular}

2003-07 average

\begin{tabular}{|c|c|c|c|c|c|}
\hline France & 4.10 & 4.41 & 0.31 & 3.95 & -0.15 \\
\hline Germany & 2.65 & 4.51 & 1.86 & 3.89 & 1.24 \\
\hline Japan & 0.97 & 1.55 & 0.58 & 1.46 & 0.49 \\
\hline United Kingdom & 5.49 & 5.32 & -0.17 & 4.68 & -0.81 \\
\hline United States & 5.68 & 4.66 & -1.02 & 4.39 & -1.29 \\
\hline Italy & 3.61 & 4.76 & 1.16 & 4.12 & 0.51 \\
\hline Greece & 7.72 & 4.94 & -2.79 & 4.14 & -3.59 \\
\hline Ireland & 7.66 & 4.15 & -3.51 & 3.92 & -3.74 \\
\hline Portugal & 3.86 & 4.67 & 0.81 & 4.02 & 0.16 \\
\hline Spain & 7.64 & 4.39 & -3.25 & 3.94 & -3.70 \\
\hline \multicolumn{6}{|l|}{ 2008-09 average } \\
\hline France & 0.08 & 4.05 & 3.97 & 3.94 & 3.86 \\
\hline Germany & -1.07 & 4.10 & 5.17 & 3.60 & 4.67 \\
\hline Japan & -4.40 & 1.44 & 5.83 & 1.42 & 5.82 \\
\hline United Kingdom & -0.30 & 4.37 & 4.67 & 3.93 & 4.23 \\
\hline United States & -0.30 & 3.93 & 4.23 & 3.45 & 3.75 \\
\hline Italy & -0.83 & 4.65 & 5.48 & 4.50 & 5.33 \\
\hline Greece & 1.77 & 4.71 & 2.95 & 4.99 & 3.22 \\
\hline Ireland & -8.01 & 4.68 & 12.68 & 4.88 & 12.89 \\
\hline Portugal & -0.20 & 4.22 & 4.42 & 4.37 & 4.57 \\
\hline Spain & 0.07 & 4.41 & 4.34 & 4.18 & 4.11 \\
\hline \multicolumn{6}{|l|}{ 2010-11 average } \\
\hline France & 2.56 & 3.21 & 0.65 & $3.12^{*}$ & 0.56 \\
\hline Germany & 4.00 & 3.25 & -0.74 & 2.74 & -1.26 \\
\hline Japan & -0.13 & 1.38 & 1.51 & 1.18 & 1.31 \\
\hline United Kingdom & 4.80 & 4.20 & -0.61 & 3.36 & -1.44 \\
\hline United States & 3.96 & 3.22 & -0.74 & 3.20 & -0.76 \\
\hline Italy & 2.27 & 4.10 & 1.83 & 4.04 & 1.77 \\
\hline Greece & -3.06 & 4.41 & 7.47 & 9.09 & 12.15 \\
\hline Ireland & -1.01 & 4.21 & 5.22 & 5.74 & 6.75 \\
\hline Portugal & 0.79 & 4.12 & 3.32 & 5.40 & 4.61 \\
\hline Spain & 1.58 & 3.62 & 2.04 & 4.25 & 2.67 \\
\hline
\end{tabular}

NOTE: GDP figures for 2011 are estimates; all rates refer to nominal variables. *The values for this column during this period refer to 2010 only. SOURCE: International Monetary Fund World Economic Outlook, IMF Fiscal Monitor, and Annual Macro-Economic (AMECO) database of the European Commission. 


\section{Figure 9}

\section{Spanish Debt Dynamics (based on 2010-11 data)}

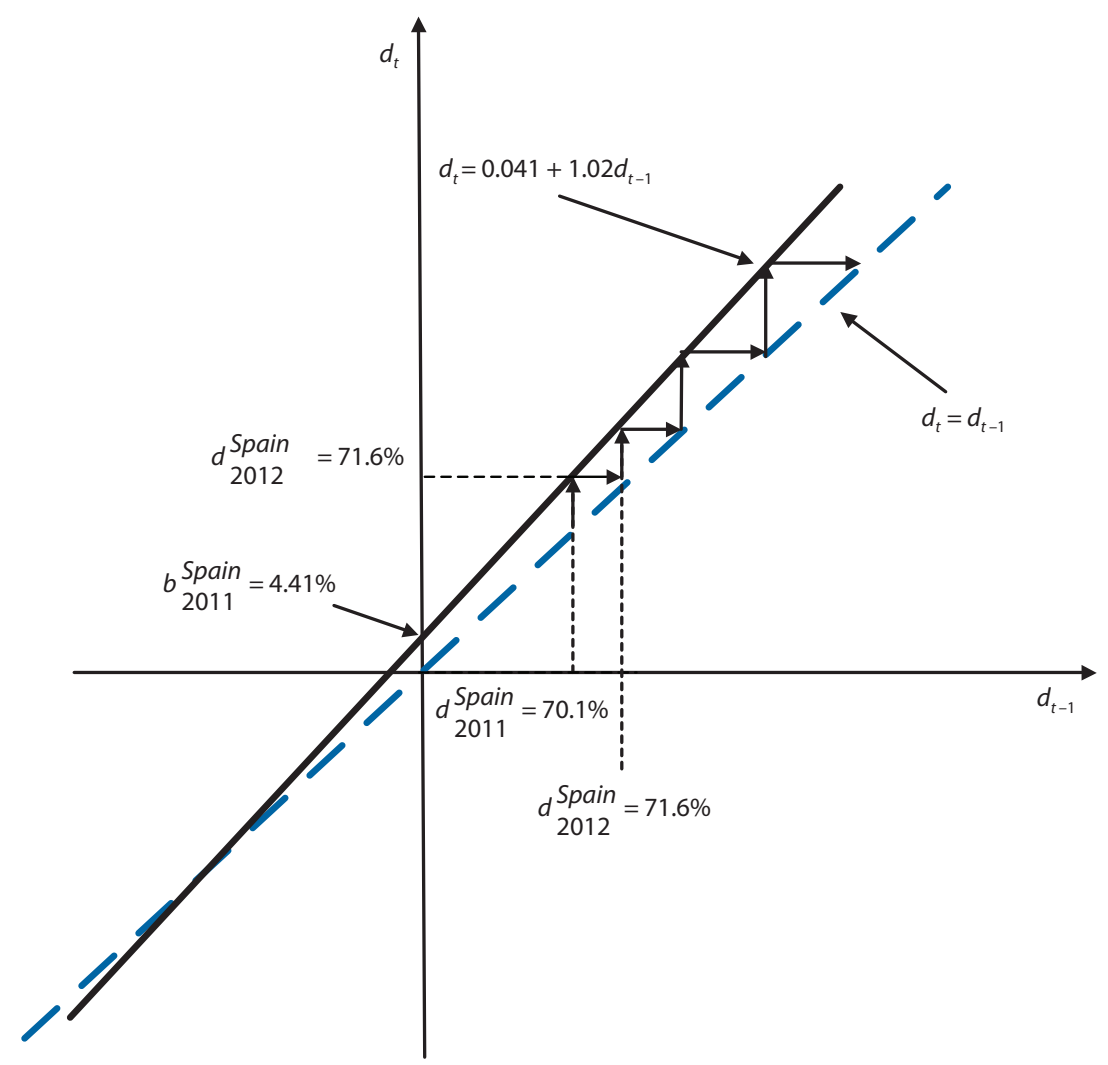

counterpart of $i_{t}$. The newest issuance of government debt in the peripheral EU countries has been accompanied by higher interest rates than those on older issuances of outstanding debt. These figures suggest that absent fiscal adjustment to reduce annual primary deficits or even generate primary surpluses (which would lower the intercept of the line describing the evolution of government debt in Figures 2, 3, and 9), countries with positive interest-growth differentials may experience continuous growth of their debt-to-GDP ratios. Therefore, these figures (i.e., larger interest-growth differentials) explain why the peripheral European countries are lumped together as potentially unsustainable.

\section{The Consequences: Rising Yield Spreads}

A consequence of the perceived unsustainability of the sovereign debts of the peripheral EU countries is the worsening of a widely used measure of stress on government debts in the euro area-the yield spread. One can pair treasury bonds with the same maturity for two countries to obtain the difference, or spread, between the yields on the two countries' securities. 


\section{Contessi}

\section{Figure 10}

Daily Spreads between Bond Yields of Seven Euro Zone Countries and Germany (10-Year Treasury Bonds)
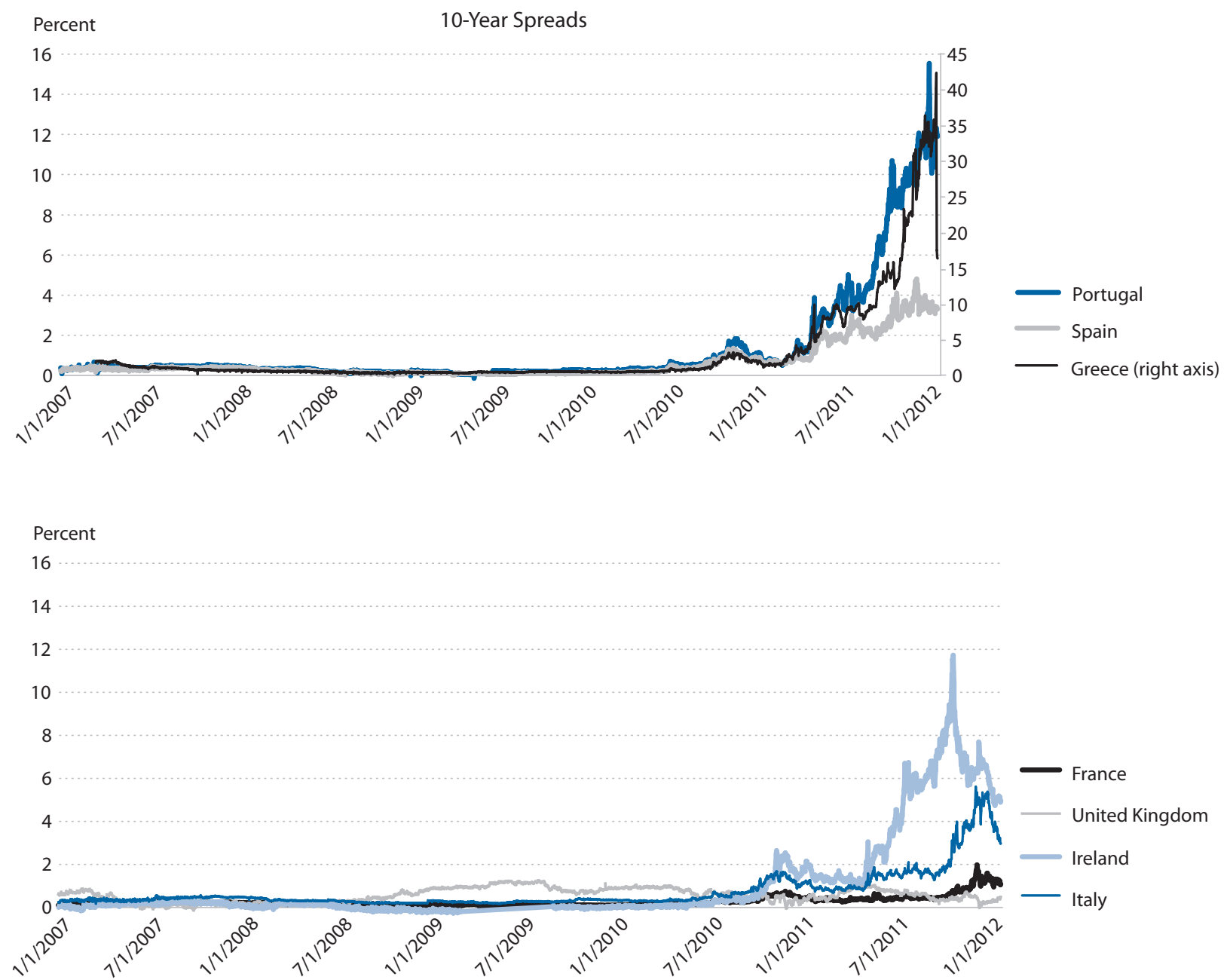

SOURCE: Haver Analytics.

Germany's sovereign debt is considered the safest in the euro zone and therefore it is normally issued with the lowest returns in the euro area. Thus, yield spreads are usually calculated as a difference between the return on German bonds with a certain maturity and the equivalent bond in the paired European country. Therefore, a common measure of stress for the government debt of individual countries is the yield spreads on a country's treasury bonds, relative to Germany's. Figure 10 plots these spreads on the yields of one such maturity-the 10-year treasury bond-for the seven euro zone countries we compare. The temporal pattern of these yields clearly shows growing tensions on European treasury bonds markets until at least the beginning of 2012. The spreads show progressive increases since the financial crisis and the worsening of the peripheral countries' status with respect to sovereign debt sustainability. Particularly note- 
worthy are the gigantic spreads on Greek debt and the large spreads for Portugal and Ireland. Italian and Spanish spreads are more contained but have also been trending upward. Finally, the bottom graph in Figure 10 shows some tension has also been observed for French sovereign debt, a fact that many observers have interpreted as the result of contagion to other EU countries. Overall, these graphs mirror the idiosyncratic problems of individual sovereign debt highlighted in Table 3 but they also point to some common trends. In particular, the reduction of sovereign debt spreads in the first three months of 2012 suggests a softening of the debt crisis, most likely due to the combination of policy interventions by the ECB, fiscal packages in various countries (that lower current and expected primary deficits), and the restructuring of the Greek debt in March 2012.

\section{CONCLUSION}

In part as a consequence of the global financial crisis and recession, several member countries of the European Monetary Union are experiencing difficulties with their fiscal balance and government debt rollover. These difficulties have prompted alarms unprecedented since World War II of (i) sovereign debt default or restructuring (for example, in Greece) and (ii) tightened fiscal discipline in an effort to reduce large and growing debt-to-GDP ratios. The five European Union countries most worrisome to markets and policymakers have quite different macroeconomic outlooks and fiscal situations but are pooled because of an underlying expectation that their national debts will not be sustainable and therefore will not be repaid in the near future.

This article has reviewed the conditions that facilitate (or hamper) sovereign debt sustainability and compared the situation of the peripheral European countries and five similar but less-troubled economies (France, Germany, Japan, the United Kingdom, and the United States). Analysis shows that the differences among the five peripheral countries can be reconciled under a traditional decomposition of the factors that affect government debt sustainability and explains why markets are worried about these particular peripheral countries collectively.

\section{NOTES}

1 There is a distinction between the EU and the European Monetary Union (EMU). The EU is a somewhat unique political and economic partnership formed by 27 European countries that resembles a confederation, while the EMU (also known as the euro zone or euro area) is a monetary union currently formed by $17 \mathrm{EU}$ countries that share a common currency, the euro, and a common monetary policy conducted by the ECB.

$\underline{2}$ In the United States, there is a difference between the public debt outstanding (i.e., the face amount or principal amount of marketable and nonmarketable securities currently outstanding) and the public debt subject to limit (i.e., the maximum amount of money the government is allowed to borrow without receiving additional authority from Congress); increasing the latter debt is commonly referred to as raising the debt ceiling.

3 Neither the ECB nor the national central bank of any member country — nor any member of their decisionmaking bodiesis allowed to seek or take instructions from (i) EU institutions or bodies, (ii) any government of an EU member state, or (iii) any other body.

4 Some countries issue debt in foreign currencies, but I do not analyze this case here. The analysis follows Jones (2009), Farmer (2002), and Walsh (2000); for more sophisticated models, see Escolano (2010) and Ley (2010).

$\underline{5}$ This component captures the idea that the government can always finance its debt by forcing the central bank to "print money" or to buy new issues of government bonds and pay with newly created money. 


\section{Contessi}

6 The source of data for these graphs is the World Economic Outlook of the International Monetary Fund. It should be noted that the data for 2011 and 2012 are projected and these projections are likely to be rather imprecise because of (i) the austerity programs implemented by many governments and (ii) the effects of the debt crisis, which may affect both GDP estimates and the cost of borrowing.

$\underline{7}$ For clarification, this is so because $\frac{r_{t}}{1+g_{t}}=\frac{r_{t}\left(1+\pi_{t}\right)}{\left(1+g_{t}\right)\left(1+\pi_{t}\right)}=\frac{r_{t}+\pi_{t}-\pi_{t}+r_{t} \pi_{t}}{1+\gamma_{t}}=\frac{\left[\left(1+r_{t}\right)\left(1+\pi_{t}\right)-1\right]-\pi_{t}}{1+\gamma_{t}}=\frac{i_{t}-\pi_{t}}{1+\gamma_{t}}$.

$\underline{8}$ Data for 2011 are projections.

\section{REFERENCES}

Bergsten, C. Fred and Kirkegaard, Jacob Funk. "The Coming Resolution of the European Crisis." Policy Brief No. PB12-1, Peterson Institute for International Economics, January 2012; www.iie.com/publications/pb/pb12-1.pdf.

Boone, Peter and Johnson, Simon. "Europe on the Brink." Policy Brief No. PB 11-13, Peterson Institute for International Economics, July 2011; www.iie.com/publications/pb/pb11-13.pdf.

Boone, Peter and Johnson, Simon. "The European Crisis Deepens." Policy Brief No. PB 12-4, Peterson Institute for International Economics, January 2012; http://piie.com/publications/pb/pb12-4.pdf.

Buehn, Andreas and Schneider, Friedrich. "Shadow Economies and Corruption All Over the World: Revised Estimates for 120 Countries." Economics: The Open-Access, Open-Assessment E-Journal, 1, 2007-9 (Version 2: October 27, 2009).

Bullard, James. “Death of a Theory." Federal Reserve Bank of St. Louis Review, March/April 2012, 94(2), pp. 83-101; http://research.stlouisfed.org/publications/review/12/03/83-102Bullard.pdf.

Escolano, Julio. "A Practical Guide to Public Debt Dynamics, Fiscal Sustainability, and Cyclical Adjustment of Budgetary Aggregates." Technical Notes and Manuals, Fiscal Affairs Department of the International Monetary Fund, January 2010, www.imf.org/external/pubs/ft/tnm/2010/tnm1002.pdf.

Farmer, Roger E.A. Macroeconomics. Cincinnati: South-Western, 2002.

Holinski, Nils; Kool, Clemens and Muysken, Joan. "Persistent Macroeconomic Imbalances in the Euro Area: Causes and Consequences." Federal Reserve Bank of St. Louis Review, January/February 2012, 94(1), pp. 1-20;

http://research.stlouisfed.org/publications/review/12/01/1-20Holinski.pdf.

Imbs, Jean. “The First Global Recession in Decades." IMF Economic Review, December 2010, 58(2), pp. 327-54.

Jones, Charles I. Macroeconomics: Economic Crisis Update. New York: W.W. Norton, 2009.

Laeven, Luc and Valencia, Fabian. "Systemic Banking Crises: A New Database." IMF Working Paper No. WP/08/224; International Monetary Union, November 2008; www.imf.org/external/pubs/ft/wp/2008/wp08224.pdf.

Ley, Eduardo. “Fiscal (and External) Sustainability." Economic Policy and Debt Department, Poverty Reduction and Economic Management ( PREM) Network, World Bank, July 18, 2010;

http://siteresources.worldbank.org/INTDEBTDEPT/Resources/468980-1207588563500/4864698-1207588597197/FSPrimer.pdf.

Martin, Fernando M. and Waller, Christopher J. “Sovereign Debt: A Modern Greek Tragedy." Federal Reserve Bank of St. Louis Annual Report 2011, forthcoming.

Reinhart, Carmen M. and Rogoff, Kenneth S. "The Aftermath of Financial Crises." American Economic Review, May 2009, 99(2), pp. 466-72.

Walsh, Carl E. Monetary Theory and Policy. Cambridge, MA: MIT Press, 2000. 


\section{APPENDIX}

\section{Seigniorage as an Inflation Tax}

The mathematical expression for seigniorage can be rewritten as follows:

$$
\begin{aligned}
& s_{t} \equiv \frac{\Delta M_{t}}{P_{t} Y_{t}}=\frac{M_{t}}{P_{t} Y_{t}}-\frac{M_{t-1}}{P_{t} Y_{t}} \\
&=m_{t}-\frac{M_{t-1}}{P_{t} Y_{t}} \frac{P_{t-1} Y_{t-1}}{P_{t-1} Y_{t-1}} \\
&=m_{t}-m_{t-1} \frac{P_{t-1} Y_{t-1}}{P_{t} Y_{t}} \\
&=m_{t}-m_{t-1}+m_{t-1}-m_{t-1} \frac{P_{t-1} Y_{t-1}}{P_{t} Y_{t}} \\
&=\Delta m_{t}+m_{t-1}\left[1-\frac{1}{\left(1+g_{t}\right)\left(1+\pi_{t}\right)}\right] \\
&=\Delta m_{t}+m_{t-1}\left[\frac{\left(1+g_{t}\right)\left(1+\pi_{t}\right)-1}{\left(1+g_{t}\right)\left(1+\pi_{t}\right)}\right] \\
& \cong \Delta m_{t}+m_{t-1} \frac{g_{t}+\pi_{t}}{1+g_{t}+\pi_{t}} .
\end{aligned}
$$

Equation (A.1) shows that seigniorage can originate from two sources. The first component $\left(\Delta m_{t}\right)$ is equal to the change in real monetary base holdings relative to GDP. The central bank is the monopoly issuer of the monetary base; an increase in the amount that the public is willing to hold allows the government/central bank to obtain real resources in exchange. When the economy is in steady-state equilibrium, $\Delta m_{t}=0$ and this source of seigniorage is null. The second component,

$$
m_{t-1} \frac{g_{t}+\pi_{t}}{1+g_{t}+\pi_{t}}
$$

can be nonzero when the economy is in steady state. The explanation for this fact is that to maintain real money holdings constant, agents in the economy must increase their nominal holdings by an amount equal to $\pi_{t}+g_{t}$, counterbalancing inflation and the real growth rate of income. If we assume that real income is not growing $\left(g_{t}=0\right)$, in steady state

$$
s_{t}=\frac{\pi_{t}}{1+\pi_{t}} m_{t-1} \cong \pi_{t} m_{t-1}
$$

for low levels of inflation. This equation shows that inflation can be considered as the product of the tax rate of $\pi_{t}$ times the tax base of $m_{t-1}$, the outstanding real stock of monetary base: Because money does not pay any interest, its real value is depreciated by inflation. Now we rearrange equation (10) according to expenditure and revenues as follows: 


\section{Contessi}

$$
\begin{aligned}
d_{t} & =\frac{\left(1+i_{t}\right)}{\left(1+g_{t}\right)\left(1+\pi_{t}\right)} d_{t-1}+b_{t}-s_{t}= \\
& =\frac{\left(1+i_{t}\right)}{\left(1+g_{t}\right)\left(1+\pi_{t}\right)} d_{t-1}-d_{t-1}+d_{t-1}-t_{t}+g_{t}-s_{t} .
\end{aligned}
$$

Rearranging terms yields

$$
\begin{gathered}
g_{t}+\frac{r_{t}-g_{t}}{1+g_{t}} d_{t-1}+\frac{r_{t}-g_{t}}{1+g_{t}} m_{t-1}=t_{t}+\left(d_{t}-d_{t-1}\right)+m_{t}-m_{t-1}+\frac{g_{t}+\pi_{t}}{1+g_{t}+\pi_{t}} m_{t-1}+\frac{r_{t}-g_{t}}{1+g_{t}} m_{t-1} \\
g_{t}+\frac{r_{t}-g_{t}}{1+g_{t}}\left(d_{t-1}+m_{t-1}\right)=t_{t}+\left[\left(d_{t}+m_{t}\right)-\left(d_{t-1}+m_{t-1}\right)\right] \frac{i_{t}}{1+g_{t}+\pi_{t}} m_{t-1} \\
g_{t}+\frac{r_{t}-g_{t}}{1+g_{t}} l_{t-1}=t_{t}+\left(l_{t}-l_{t-1}\right)+\frac{i_{t}}{1+g_{t}+\pi_{t}} m_{t-1},
\end{gathered}
$$

where total liabilities of the government in real terms $\left(l_{t}\right)$ are the sum of real government debt $\left(d_{t}\right)$ and the real stock of money $\left(m_{t}\right)$. The component that represents seigniorage in this equation $\left[i_{t} /\left(1+g_{t}+\pi_{t}\right)\right]^{*} m_{t-1}$ depends directly on the nominal interest rate. In this formulation, it should be clear that seigniorage represents an alternative way to finance expenditure relative to issuing debt (that bears an interest $i_{t}$ ): The larger the amount of money issued by the government relative to nominal GDP, the larger the share of government expenditure that can be financed by an interest-free liability. 